\title{
Recenzja książki Leszek Gawor, 2017, Ekoszkice, Wydawnictwo Uniwersytetu Rzeszowskiego, Rzeszów
}

\author{
Anna Wódczak-Kalińska \\ e-mail: annawkalinska@gmail.com
}

Współczesny świat i jego zmieniające się uwarunkowania wskazują na to, że wegetarianizm obecnie zyskuje wielu sympatyków i toczy się przez to ożywiona dyskusja nad zmianą statusu zwierząt oraz całego świata przyrody. Jest ona inspirowana między innymi coraz liczniejszymi publikacjami naukowymi na ten temat. Także Leszek Gawor w swych „Ekoszkicach” zajął się tą problematyką. W momencie, w którym zainteresowanie problemami ekologicznymi wyraźnie osłabło, treść tej publikacji nabrała nieoczekiwanie nowego znaczenia. Można ją potraktować jako głos świata nauki przypominającego o ciągle nierozwiązanym kryzysie ekologicznym, którego nadal doświadcza cały nasz glob. Autor prezentuje jednak stanowisko, którego nie można zastosować w praktyce, chociażby ze względu na ewolucyjnie uwarunkowaną pozycję człowieka w świecie przyrody. Postulat: „Należy zrewidować błędną, jak się okazuje, antropocentryczną wizję człowieka w świecie i zastąpić ją perspektywą ekocentryczną, w której człowiek zajmuje niewyróżnioną pozycję wśród innych składników przyrody" (s. 8). Jest wobec powyższego deklaracją, która zapewne nie zyska społecznego poparcia. Pewne postulaty zawarte $\mathrm{w}$ niej jednak nie zostały ukazane z merytorycznie pewną konsekwencją ekologiczną.
Usytuowanie ludzkiego gatunku w przyrodzie jest wyróżnione przez samą naturę. Człowiek, zajmując niewyróżnioną pozycję wśród pozostałych elementów przyrody, nie mógłby pełnić swej zasadniczo opiekuńczej roli w stosunku do niej. Antropocentryzm nie musi iść $\mathrm{w}$ parze $\mathrm{z}$ szowinizmem gatunkowym, który w rzeczy samej prowadzi do nieuniknionego zakłócenia harmonii świata przyrody, do której bezsprzecznie człowiek współnależy. Destrukcja taka rodzi bowiem skutki natury globalnej, której negatywnym skutkiem może być samozagłada ludzkości. Niszcząc środowisko naturalne, człowiek pozbawia się podstaw własnej egzystencji, z których „wyrósł”, dzięki którym jest w stanie przetrwać od początku swego istnienia.

Leszek Gawor źródeł tego procesu upatrywać zdaje się w obniżaniu statusu poznania naukowego w kulturze ogólnoludzkiej: „Współczesny świat (...) poddany jest jakby procesowi rozszczepiania na środowiska kultywujące poznanie naukowe i pozostałą, przeważającą część społeczeństwa poszukującą sensowności świata albo to w dogmatycznym nauczaniu różnych kościołów, albo w konstruowaniu światopoglądu z (...) najczęściej irracjonalnych składników (np. neopoganie, ufolodzy, realianie). (...) Może i też ów postęp ludzkiego poznania być dezawuowany z pozycji irracjonalnego 
światopoglądu lub określonej wizji ideologicznej. Tym samym wartość naukowego poznania przestaje być wiodącą na drodze dziejowej cywilizacji człowieka" (s. 14). Takie schematyczne dzielenie społeczeństwa globalnego na część racjonalną i irracjonalną nie może być pomysłem na uzdrowienie świata. Nie ma także wystarczających danych uzasadniających tezę, iż społeczeństwa mają tendencję do konstruowania irracjonalnych światopoglądów. Z drugiej strony w książce zabrakło uzasadnionych informacji, aby potwierdzić tezę przeciwną. Historia nauki bogata jest w fakty wskazujące na to, że pewne ideologie bywają najpierw odrzucane, a potem stają się podwalinami nowych regulacji prawnych i społecznych przyjmowanych także przez świat nauki. Trafnym przykładem może być Ruch Wyzwolenia Zwierząt zapoczątkowany przez Petera Singera, który najpierw obejmował bardzo nieliczną grupę ludzi rzeczywiście zainteresowanych eliminacją niepotrzebnego cierpienia zwierząt (m.in. hodowlanych, laboratoryjnych), zanim w ogóle zaczął być poważnie traktowany przez środowisko naukowe.

Co istotne, rolą nauki nie może być dyskredytowanie środowisk nieaprobujacych scjentyczny obraz świata, którym bezpodstawnie odmawia się prawa do poszukiwań sensowności świata tylko ze względu na to, że ich punkt widzenia nie został jeszcze wystarczająco zbadany lub uzasadniony. Zasadniczą jej funkcją jest oświecanie, zbliżenie do prawdy poprzez racjonalną argumentację. Nie można jednak wykluczyć, iż niektóre z niepoznanych przez nas jeszcze gruntownie idei (jak dotąd uważanych za irracjonalne) zaczną się w przyszłości rozwijać na gruncie nauki. Dlatego powinna ona otworzyć się na nowe możliwości, jeśli faktycznie pragnie nadal się rozwijać. W świecie tak zróżnicowanym pod względem kulturowym i pełnym zagrożeń - nie tylko z racji obecnego kryzysu migracyjnego, ale i zawirowań politycznych i społecznych konfliktów - konieczną jest zmiana mentalności w skali globalnej, aby nasza troska ekologiczna mogła mieć jakikolwiek sens.
Publikacja Leszka Gawora, ze swymi luźno powiązanymi rozdziałami-szkicami, nie posiada charakteru podręcznika przeznaczonego dla czytelników dopiero poszukujących wiedzy o problemach ekologicznych. Jest jednak cenną literaturą dla zaawansowanych odbiorców. Co prawda, pewne treści zdają się mieć zabarwienie subiektywne. Autor sugeruje, iż „wyczerpywanie się eksploatowanych bez umiaru nieodnawialnych surowców kopalnych (...) związane jest z gospodarką współczesnego człowieka opartą na pozyskiwanych ze środowiska naturalnego przede wszystkim surowców energetycznych i innych oraz na dogmacie stałego wzrostu gospodarczego (...). Pierwszym uzasadnieniem takiego działania jest stały wzrost potrzeb wynikający z ciągłego przyrostu populacji ludzkiej" (s. 23). To prawda, warunki i jakość ludzkiego życia oraz egzystencja innych gatunków bez wątpienia zależą od tych zasobów. Jednakże dyskusyjnym jest, iż przyczyną tego stanu rzeczy mógłby być „przyrost populacji ludzkiej”. Autor powołuje się na niektóre źródła internetowe (Gazeta Wyborcza, Wikipedia, Onet), które dla naukowca nie mogą stanowić wiarygodnego źródła informacji w tym zakresie. Zarazem subiektywne opinie autorów internetowych, często w ogóle niepowiązanych z nauką, mogą znacząco zniekształcić ocenę sytuacji, a przez to negatywnie wpłynąć na postawy i poglądy społeczności. Leszek Gawor postuluje, że przyrost ludności jest przyczyną problemów, biorąc pod uwagę archaiczną i niemającą dziś swego potwierdzenia w świecie koncepcję Malthusa traktującą istnienie na świecie wojen, epidemii i głodu - „jako zdarzenie zmniejszające liczbę mieszkańców Ziemi” (s. 25). Takie stanowisko prowadzi do propagowania teorii uzasadniających konieczność stosowania metod depopulacji jako potencjalnych rozwiązań problemów ekologicznych. Sądzę, iż ów zagrażający naszej egzystencji niekontrolowany przyrost ludności nie znajduje wsparcia w wynikach badań naukowych, toteż argumenty autora o popieraniu konieczności zmniejszenia liczby ludzi na Ziemi nie 
miałyby w chwili obecnej przekonywującego uzasadnienia.

Postulat o niedostatku obszaru gruntów uprawnych: „Ziemia nie będzie w stanie przy wzroście ludności wyżywić nas albo że już niedługo ludzkości zagrozi globalny głód” (s. 24). Zapobiec głodowi na skalę globalną można bowiem w bardzo prosty sposób i można tego dokonać bez ponoszenia dodatkowych kosztów na środowisko naturalne, przyczyniając się jednocześnie do jego ochrony. Wystarczy przykładowo zaprzestać lub choćby znacznie ograniczyć jedzenie mięsa. Zdecydowana większość upraw jest bowiem wymuszana zapotrzebowaniem na paszę dla zwierząt hodowlanych.

Świadomość ekologiczna w społeczeństwie jest coraz większa, o czym znajdujemy potwierdzenie w książce. Przesłanki wskazujące na jej zaistnienie to przede wszystkim „znajomość procesów zachodzących w ekosferze i poszczególnych ekosystemach”, wiedza „o zależnościach i wzajemnych powiązaniach stanowiących o równowadze systemu”, wiedza „o zależnościach między różnymi sferami działalności człowieka a środowiskiem”, wiedza „o zagrożeniach środowiskowych" i wiele innych czynników związanych z działaniami człowieka na rzecz przyrody (ss. 85-86). Napawa to optymizmem, gdyż należy mieć na uwadze, że transformacja świadomości na proekologiczną jest faktem i dziś w zasadzie określa kierunek rozwoju ludzkości.

Postulaty metanoi i homo ecologicus u Gawora to potwierdzenie realnej przemiany w świadomości ekologicznej, a zarazem nadzieja na punkt zwrotny w poglądzie człowieka na środowisko (s. 96). Stanowią naturalną wyjściową koncepcji zrównoważonego rozwoju, wedle której człowiek, zamiast zawłaszczać dla własnych celów świat przyrody, jaki sobie podporządkował, pragnie jego dobra (nie zniszczenia) $\mathrm{i}$ - poprzez swoją aktywność w nim - dokonuje praktycznych przeobrażeń. Aby mogło to nastąpić, niezbędna jest wewnętrzna przemiana, metanoja, która zachodzi w człowieku dopiero w wyniku uświadomienia sobie nadmiernej i destrukcyjnej eksploatacji środowiska (ss.112-113). Taka metanoja jest niezbędna, by człowiek zatrzymał się w tym dążeniu do samozniszczenia i obrał inną (lepszą) drogę rozwoju.

Oprócz odniesień autora do ekologii, znajdujemy w tej pozycji też stanowisko w zakresie sozologii, ekofilozofii czy sozofilozofii - nurtów, które wyłoniły się w wyniku rozwoju myśli ekologicznej i filozoficznej. Prace z zakresu ochrony przyrody opublikowane na początku XXI w., a pisane ręką filozofów, ekologów oraz innych osób zainteresowanych problematyką ekologiczną, skłaniają ku refleksji, że oto pojawiła się nowa obszerna dziedzina nauki, którą autor słusznie określa "filozofią ochrony środowiska" (ss. 166-167).

Ekoszkice to pozycja popularnonaukowa w swej formie, na którą składają się luźne opracowania z wielu różnych dziedzin, mające jednak wspólną oś problemową. Przeznaczona dla czytelnika posiadającego już podstawową wiedzę z zakresu ekologii. Książka zawiera szereg cennych informacji dotyczących historii idei ochrony środowiska. Opisuje, sięgające nawet 1122 roku p.n.e., początki tej idei oraz wskazuje głównych propagatorów ruchu ochrony środowiska, kończąc na dziejach polskiej myśli ekologicznej, co niewątpliwie jest atutem tej pozycji. Dość dobrze opisane są zagrożenia środowiska naturalnego, takie jak efekt cieplarniany, dziura ozonowa, kwaśne deszcze, obumieranie lasów oraz zanieczyszczenie odpadami. Dzięki tym informacjom posiada określoną wartość edukacyjną. Osobiste refleksje autora nie zawsze pokrywają się z poglądami wymienionych przedstawicieli ruchu ekologicznego, przez co czytelnik może odnieść wrażenie niespójności merytorycznej. Autor ma jednak prawo do własnej interpretacji myśli twórców innych idei. Książka w wersji poszerzonej zyskałaby na wysunięciu określonych postulatów wraz z propozycjami konkretnych rozwiązań. Warto do niej sięgnąć jeszcze z innego powodu, który winien być potraktowany priorytetowo przez każdego z nas. Może 
stanowić rozsądną propozycję, jeśli za cel obrać dokonanie realnych, a nie tylko teoretycznych, zmian w ochronie środowiska. Cytując autora: „Znajdujemy się w czasie wzmożonego ekologicznego kryzysu i musimy w sposób konieczny podjąć natychmiastowe działania chroniące naturę (także i środowisko społeczne), dzięki którym ludzkość ma szanse na dalsze istnienie" (s. 202). Poprzez sam opis koncepcji, bez podjęcia realnych kroków popierających te idee, ludzkość nie będzie w stanie ochronić ani gatunku, ani otoczenia, w którym żyje. Jednak kształtowanie świadomości ekologicznej zaczyna się ni mniej, ni więcej od myśli. Ona natomiast jest zaczątkiem czynu. Jest to proces na tyle długotrwały i zróżnicowany ewolucyjnie, iż nie sposób określić odległych w czasie konsekwencji przemiany świadomości ekologicznej człowieka. Warto jednak podjąć ów wysiłek. Jakkolwiek czynimy to ostatecznie dla nas samych i następnych pokoleń. 